OPEN ACCESS

Edited by:

Christian Lindemann, University of Bergen, Norway

Reviewed by: Kemal Can Bizsel, Institute of Marine Sciences and Technology, Turkey Bruno Buongiorno Nardelli, National Research Council, Italy

*Correspondence: Leonardo Laiolo Leonardo.Laiolo@gmail.com

Specialty section: This article was submitted to Marine Ecosystem Ecology, a section of the journal Frontiers in Marine Science

Received: 10 June 2016 Accepted: 16 August 2016 Published: 30 August 2016

Citation:

Laiolo L, Mclnnes AS, Matear R and Doblin MA (2016) Key Drivers of Seasonal Plankton Dynamics in Cyclonic and Anticyclonic Eddies off East Australia. Front. Mar. Sci. 3:155. doi: 10.3389/fmars.2016.00155

\section{Key Drivers of Seasonal Plankton Dynamics in Cyclonic and Anticyclonic Eddies off East Australia}

\author{
Leonardo Laiolo ${ }^{1,2 *}$, Allison S. Mclnnes ${ }^{1}$, Richard Matear ${ }^{2}$ and Martina A. Doblin ${ }^{1}$ \\ ${ }^{1}$ Climate Change Cluster, University of Technology Sydney, Ultimo, NSW, Australia, ${ }^{2}$ Oceans and Atmosphere, CSIRO, \\ Hobart, TAS, Australia
}

Mesoscale eddies in the south west Pacific region are prominent ocean features that represent distinctive environments for phytoplankton. Here, we examine the seasonal plankton dynamics associated with averaged cyclonic and anticyclonic eddies (CE and ACE, respectively) off eastern Australia. We do this through building seasonal climatologies of mixed layer depth (MLD) and surface chlorophyll-a for both CE and ACE by combining remotely sensed sea surface height (TOPEX/Poseidon, Envisat, Jason-1, and OSTM/Jason-2), remotely sensed ocean color (GlobColour) and in situ profiles of temperature, salinity and pressure from Argo floats. Using the CE and ACE seasonal climatologies, we assimilate the surface chlorophyll-a data into both a single (WOMBAT), and multi-phytoplankton class (EMS) biogeochemical model to investigate the level of complexity required to simulate the phytoplankton chlorophyll-a. For the two eddy types, the data assimilation showed both biogeochemical models only needed one set of parameters to represent phytoplankton but needed different parameters for zooplankton. To assess the simulated phytoplankton behavior we compared EMS model simulations with a ship-based experiment that involved incubating a winter phytoplankton community sampled from below the mixed layer under ambient and two higher light intensities with and without nutrient enrichment. By the end of the 5-day field experiment, large diatom abundance was four times greater in all treatments compared to the initial community, with a corresponding decline in pico-cyanobacteria. The experimental results were consistent with the simulated behavior in CE and ACE, where the seasonal deepening of the mixed layer during winter produced a rapid increase in large phytoplankton. Our model simulations suggest that CE off East Australia are not only characterized by a higher chlorophyll-a concentration compared to ACE, but also by a higher concentration of large phytoplankton (i.e., diatoms) due to the shallower CE mixed layer. The model simulations also suggest the zooplankton community is different in the two eddy types and this behavior needs further investigation.

Keywords: data assimilation, mesoscale features, phytoplankton dynamics, zooplankton dynamics, biological oceanography, size based model 


\section{INTRODUCTION}

Mesoscale eddies play crucial roles in ocean circulation and dynamics, stimulating phytoplankton growth and enhancing the global primary production by $\sim 20 \%$ (Falkowski et al., 1991; McWilliams, 2008). Usually, eddies occur where there are strong currents and oceanic fronts (Robinson, 1983) and hence are a common feature of western boundary currents (Chelton et al., 2011). The direction and resulting temperature of an eddy circulation can be categorized as either cyclonic cold core or anticyclonic warm-core (Robinson, 1983). The cyclonic eddies (CE) are associated with low sea level anomalies, doming of the isopycnals and shoaling of the nutricline (Falkowski et al., 1991; McGillicuddy, 2015). The shoaling of the nutricline helps supply nutrient-rich waters to the euphotic zone when mixed layer depth (MLD) undergoes seasonal deepening (Dufois et al., 2014; McGillicuddy, 2015) and, thereby stimulating phytoplankton growth (Jenkins, 1988; Falkowski et al., 1991; McGillicuddy and Robinson, 1997). In contrast, anticyclonic eddies (ACE) are associated with high sea level anomalies, depression of the isopycnals and deepening of the nutricline (McGillicuddy, 2015). The MLD of ACEs is generally deeper than CEs (Dufois et al., 2014) and this changes the supply of nutrients to the euphotic zone when the eddy undergoes seasonal deepening of the MLD with additional impacts to light levels (Dufois et al., 2014; McGillicuddy, 2015). While representing different physical and nutrient conditions, the characteristics of $\mathrm{CE}$ and ACE can also differ because of differences in how these eddies form. The process called "eddy trapping" (McGillicuddy, 2015) was used to describe how composition of the water trapped in an eddy depends on the process of eddy formation as well as on the local gradients in physical, chemical, and biological properties. One example is the formation of eddies off Western Australian where the Leeuwin Current generates ACE initialized with high Chl-a derived from the coastal water (Moore et al., 2007).

CE and ACE represent two distinct environments because of differences in their physical properties and in the physical processes that form them, which can lead to different phytoplankton abundance, biomass, and composition (Angel and Fasham, 1983; Arístegui et al., 1997; Arístegui and Montero, 2005; Moore et al., 2007; Everett et al., 2012, Table 1). In addition, sub-mesoscale processes can affect phytoplankton dynamics in mesoscale eddies (Klein and Lapeyre, 2009); in particular smallscale upwellings and downwellings seem to have a significant impact on phytoplankton subduction and primary production (Levy et al., 2001).

Multiple processes can impact phytoplankton composition and growth in mesoscale eddies. Oceanographic studies show that large photosynthetic eukaryotes $(>3 \mu \mathrm{m}$, diatoms in particular) appear confined to the center of CE (Rodriguez et al., 2003; Brown et al., 2008). In comparison, higher concentrations of cyanobacteria $(<3 \mu \mathrm{m})$ are located in the surrounding oligotrophic waters (Olaizola et al., 1993; Rodriguez et al., 2003; Vaillancourt et al., 2003; Brown et al., 2008) and in adjacent ACEs (e.g., Haury, 1984; Huang et al., 2010). However, we still have very limited understanding about the phytoplankton communities
TABLE 1 | Schematic representation of main physical and biological differences between CE and ACE off East Australia.

\begin{tabular}{lll}
\hline Eddy properties & \multicolumn{2}{c}{ Eddy type } \\
\cline { 2 - 3 } & ACE (warm core) & CE (cold core) \\
\hline Direction of circulation & Counter clockwise & Clockwise \\
Vertical structure & Downwelling & Upwelling \\
Sea surface height anomalies & Positive & Negative \\
Dissolved nutrient concentration & Lower & Higher \\
Mixed layer depth & Deeper & Shallower \\
Chlorophyll a concentration & Lower & Higher \\
\hline
\end{tabular}

that characterize eddy environments because they remain largely under-sampled.

Phytoplankton are limited by two primary resources in marine environments: light and nutrients (Behrenfeld and Boss, 2014). Eddies represent an interesting resource paradox because, through physical processes, they influence light and nutrient concentrations simultaneously. Indeed, the seasonal deepening of the MLD can bring nutrient-rich water from depth into the euphotic zone but decrease the total photon flux to cells. Due to the differing nutrient requirements of phytoplankton, the water mass below the MLD could therefore play an important role in determining eddy phytoplankton concentration and composition (Bibby and Moore, 2011; Dufois et al., 2016). Furthermore, the shallower MLD that characterizes CE leads to higher light levels in the surface mixed layer, while ACE have lower light levels (Tilburg et al., 2002). Understanding what the primary driver of phytoplankton dynamics in these two environments is an important question, given the uncertainty in regional predictions of primary production under projected ocean change (Bopp et al., 2013).

Floristic shifts in phytoplankton at a regional level will play an important role in determining the marine ecosystem response to future climate change (Boyd and Doney, 2002). Representation of phytoplankton in biogeochemical models ranges in complexity from a single phytoplankton compartment to multi-phytoplankton compartments that can be separated into different functional groups and/or sizes (Fennel and Neumann, 2004). To advance knowledge about the physical-biological interactions in mesoscale features and reduce uncertainty, McGillicuddy (2015) suggests coupling in situ observations, remote sensing, and modeling. Here, we follow such an interdisciplinary approach.

Our study area is eastern Australia (Figure 1), a region strongly influenced by the southward flowing Eastern Australian Current (EAC), which forms both CE and ACE (Hamon, 1965; Tranter et al., 1986). EAC waters are low in nutrients and any subsurface nutrients are rarely upwelled to the euphotic zone (Oke and Griffin, 2011). However, increases in phytoplankton biomass occur in this region as a response to occasional upwelling-favorable wind events, the separation of the EAC from the shelf or the formation of CE (Tranter et al., 1986; Cresswell, 1994; Roughan and Middleton, 2002). Both eddy types form from meanders in the EAC and move into adjacent water with different 


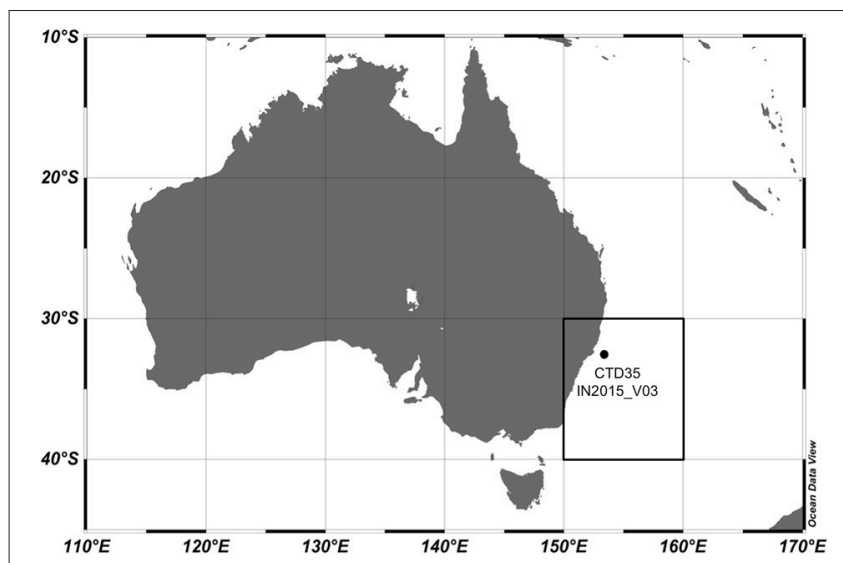

FIGURE 1 | Map showing the study area, including the location of the where water was collected for the shipboard manipulation experiment (CTD35 IN2015_V03).

physical, chemical, and biological characteristics (Lochte and Pfannkuche, 1987).

Here, we characterize phytoplankton dynamics in CE and ACE off East Australia using a combination of in situ observations, remote sensing, and modeling. We firstly explore the level of phytoplankton complexity required to estimate the phytoplankton chlorophyll-a (Chl-a) for eddies in the East Australian system, using a single (WOMBAT) and a multi-phytoplankton class model (EMS). Models were used to simulate the observed Chl-a concentrations obtained from satellites (MERIS, SeaWiFS, and MODIS-Aqua). Shifts in phytoplankton composition and size distribution were also examined using a manipulative ship-board experiment and comparing outcomes with simulations. Results show that CE and ACE off eastern Australia are not only characterized by a different Chl-a concentration but also by different phytoplankton composition. Both models suggest these differences are related to distinct zooplankton dynamics. Furthermore, simulation results are consistent with the ship-based experiment, highlighting the important role of MLD and irradiance in driving eddy phytoplankton dynamics off eastern Australia.

\section{MATERIALS AND METHODS}

\section{Study Region and Location of Voyage Experiment}

The eastern Australian ocean region is significant for Australia's economy and marine ecology (Hobday and Hartmann, 2006). This area is adjacent to capital cities, major shipping lanes and regions of environmental significance (e.g., Great Barrier Reef World Heritage area). Pelagic offshore fisheries, including the valuable Bluefin tuna, are strongly influenced by the EAC, the major western boundary current of the South Pacific subtropical gyre (Mata et al., 2000; Ridgway and Dunn, 2003; Hobday and Hartmann, 2006; Brieva et al., 2015). Furthermore, the ocean circulation of this region has a crucial role in removing heat from the tropics and releasing it to the mid-latitude atmosphere (Roemmich et al., 2005). In this region, climate change is projected to increase eddy activity and hence primary productivity (Matear et al., 2013). Due to its importance, the area selected for this study is located between $30^{\circ}$ and $40^{\circ} \mathrm{S}$, and $150^{\circ}$ and $160^{\circ} \mathrm{E}$ (Figure 1).

\section{Description of Biogeochemical Models}

To explore the level of complexity required to represent seasonal phytoplankton dynamics associated with mean MLD variations in $\mathrm{CE}$ and ACE within the domain, two biogeochemical models were used. The first model, "WOMBAT" (Whole Ocean Model of Biogeochemistry And Trophic-dynamics) is a Nutrient, Phytoplankton, Zooplankton and Detritus (NPZD) model, with one zooplankton and one phytoplankton class (i.e., total Chl-a concentration) characterized by a fixed C:Chl-a ratio (Kidston et al., 2011, Figure 2A). WOMBAT has a total of 14 different parameters. The second NPZD biogeochemical model, Environmental Modeling Suite (EMS), is a more complex size-dependent model characterized by a total of 104 parameters (CSIRO Coastal Environmental Modelling Team, 2014). EMS has been developed to model coupled physical, chemical, and biological processes in marine and estuarine environments (CSIRO Coastal Environmental Modelling Team, 2014) and can be implemented in a wide range of configurations. We set it up with two phytoplankton and two zooplankton classes, characterized by different sizes, growth, mortality, and grazing rates (zooplankton only; Figure 2B). The two EMS phytoplankton classes can adjust their C:Chl-a ratio daily, to attain the ratio that allows optimal phytoplankton growth (Baird et al., 2013).

Both biogeochemical models are configured as $0 \mathrm{D}$ to represent a well-mixed MLD with a prescribed seasonal cycle of nutrient levels below the MLD. Phytoplankton and zooplankton concentrations are uniformly distributed in the MLD. The MLD climatology was the only environmental factor differing between the $\mathrm{CE}$ and ACE systems. The time series of temperature in the MLD and nutrients below the MLD from the CSIRO Atlas of Regional Seas dataset (CARS; http://www.marine.csiro. au/ dunn/cars2009/; Ridgway et al., 2002) were used in the simulations, with no distinction between the eddy environments. The surface incident irradiance comes from seasonal climatology of the region (Large and Yeager, 2008). Because other physical phenomena, such as upwelling or downwelling were not explicitly represented, the only supply of nutrients to the MLD occurs with the deepening of the MLD (i.e., when the MLD is shoaling there is no new supply of nutrients to the MLD). In both models, when the MLD is deepening from a time step to the next one, the nutrient concentration (calculated from the nitrate dataset below the MLD obtained from CARS; Ridgway et al., 2002) is added to the MLD. Following Matear (1995) approach the nutrients concentration added in the MLD is calculated as:

$$
\mathrm{N}_{\mathrm{t}+1}=\frac{\delta \mathrm{h} \cdot \mathrm{N}_{\mathrm{b}}+\mathrm{h} \cdot \mathrm{N}_{m}}{\mathrm{~h}+\delta \mathrm{h}}
$$

where $h$ represents the MLD, $\delta$ h the difference in the MLD between the time $t$ and $t+1, \mathrm{~N}_{\mathrm{b}}$ represent the nutrient 

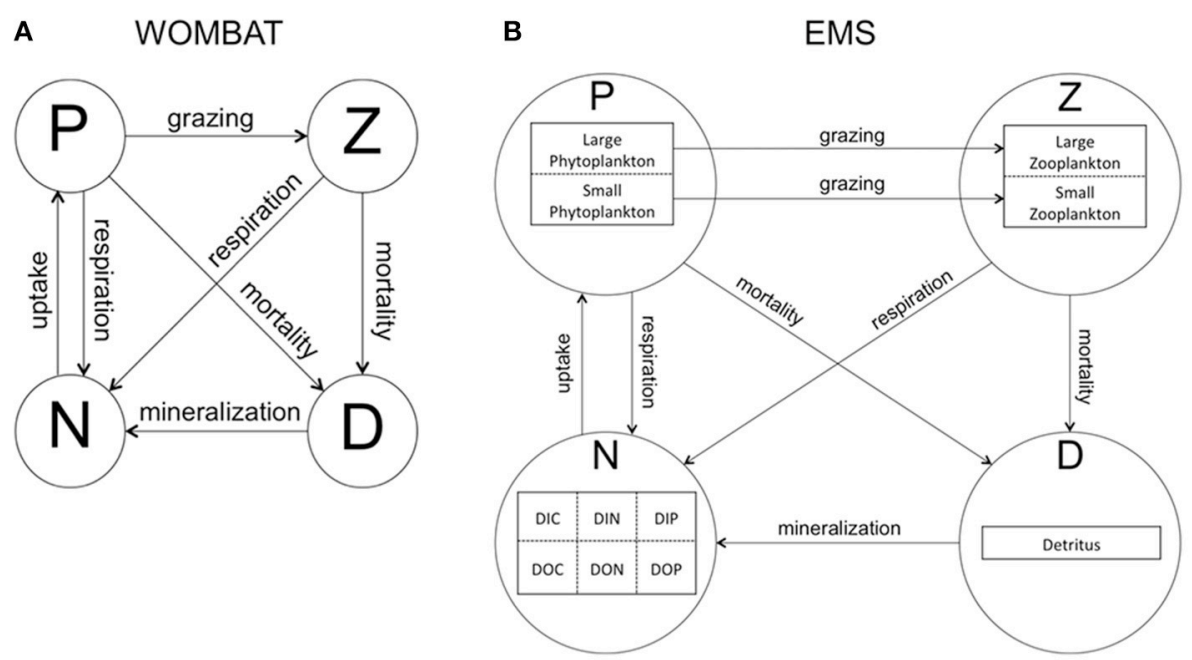

FIGURE 2 | Structure of biogeochemical models used in this study. Arrows represent interactions and links between model compartments. (A) WOMBAT (Whole Ocean Model of Biogeochemistry And Trophic-dynamics), which has one phytoplankton (P) and one zooplankton (Z) class, detritus (D), and one nutrient compartment (N). (B) EMS (Environmental Modeling Suite), characterized by two phytoplankton (P) and zooplankton (Z) sized-based classes, detritus (D) and one nutrient compartment divided into dissolved inorganic carbon, nitrogen, phosphate (DIC, DIN, DIP), and dissolved organic carbon, nitrogen, phosphate (DOC, DON, DOP).

concentration below the MLD, $\mathrm{N}_{m}$ the nutrient concentration in the MLD.

To evaluate the sensitivity of the model to higher-frequency variations in the MLD, we added Gaussian random noise to the CE and ACE daily MLD dataset, where the standard deviation of the random noise was estimated from the standard error of the CE and ACE MLDs (i.e., ACE $1.3 \mathrm{~m}$; CE $1.2 \mathrm{~m}$ ).

\section{Input Data and Implementation to Biogeochemical Models}

Because of their different dynamical balances, ACE and CE can be identified through sea surface height anomalies (SSH) detected by satellites (Lee-Lueng et al., 2010). A 17 year, 8-day composite dataset of SSH anomalies (2 September, 1997-26 September, 2014), was downloaded from AVISO (Delayed-Time Reference Mean Sea-Level Anomaly; http://www.aviso.altimetry. $\mathrm{fr} / \mathrm{en} /$ data/products/sea-surface-height-products.html). Eddies were identified by prescribing $\pm 0.2 \mathrm{~m} \mathrm{SSH}$ anomaly threshold that characterizes ACE and CE, respectively (Pilo et al., 2015). Satellite-derived Chl-a measurements $(25 \mathrm{~km}$ spatial resolution, 8 -day average) were downloaded from GlobColour (an ocean color product that combines output from MERIS, SeaWIFS, and MODIS; http://hermes.acri.fr/index.php?class=archive). Using this kind of product ensures data continuity, improves spatial and temporal coverage and reduces noise (ACRIST GlobColour Team et al., 2015). To obtain MLD measurements, Argo data (temperature, salinity, time, pressure, location for every Argo Float) were downloaded from the GODAE (Global Ocean Data Assimilation Experiment; http://www.usgodae.org/cgi-bin/argo_select.pl). The MLD value was defined as the depth where temperature changed by $1^{\circ} \mathrm{C}$ and density by $0.05 \mathrm{~kg} \mathrm{~m}^{-3}$ from the surface value (Brainerd and Gregg, 1995; de Boyer Montegut et al., 2004; Dong et al.,
2008). The climatology of surface water (5 m) temperature and nitrate concentration below the MLD was obtained from CARS (Figure 3; Ridgway et al., 2002); while we obtained the irradiance from the seasonal climatology of the downward short wave radiation at the surface of the ocean (Large and Yeager, 2008). Before inputting to the models, all data were filtered to exclude locations shallower than $1000 \mathrm{~m}$, to avoid including data from coastal systems.

The Chl-a and MLD datasets obtained from GlobColour and GODAE were mapped in time and space onto the 8-day averaged CE and ACE SSH fields. Thus, we obtained surface Chla concentrations and MLDs for CE and ACE off East Australia occurring from 1 December 2002 to 1 December 2014 in an 8day averaged dataset (Argo data are not available before 2002 in our domain). Chl-a concentration and MLD were averaged over time periods $(n=546)$ at their original resolution, obtaining a Chl-a and a MLD 8-day averaged seasonal climatology for an idealized $\mathrm{CE}$ an ACE of the selected East Australia region (Figure 4). The datasets extracted from CARS (nitrogen, temperature, and light) were used in the two biogeochemical models without any distinction between CE and ACE, as the available data from CARS are an average of the whole area of study.

\section{Statistical Analysis and Goodness of the Fit}

The student $t$-test was performed to assess statistical differences between the CE and ACE Chl-a climatologies, calculated from the GlobColour dataset. The same approach was applied to the MLD climatology derived from the GODAE Argo dataset. The same test was used to asses if there were statistical differences between the average of the observed and modeled data (i.e., GlobColour Chl-a climatology vs. simulated Chl-a), with significance for all tests defined as $p<0.05$. 

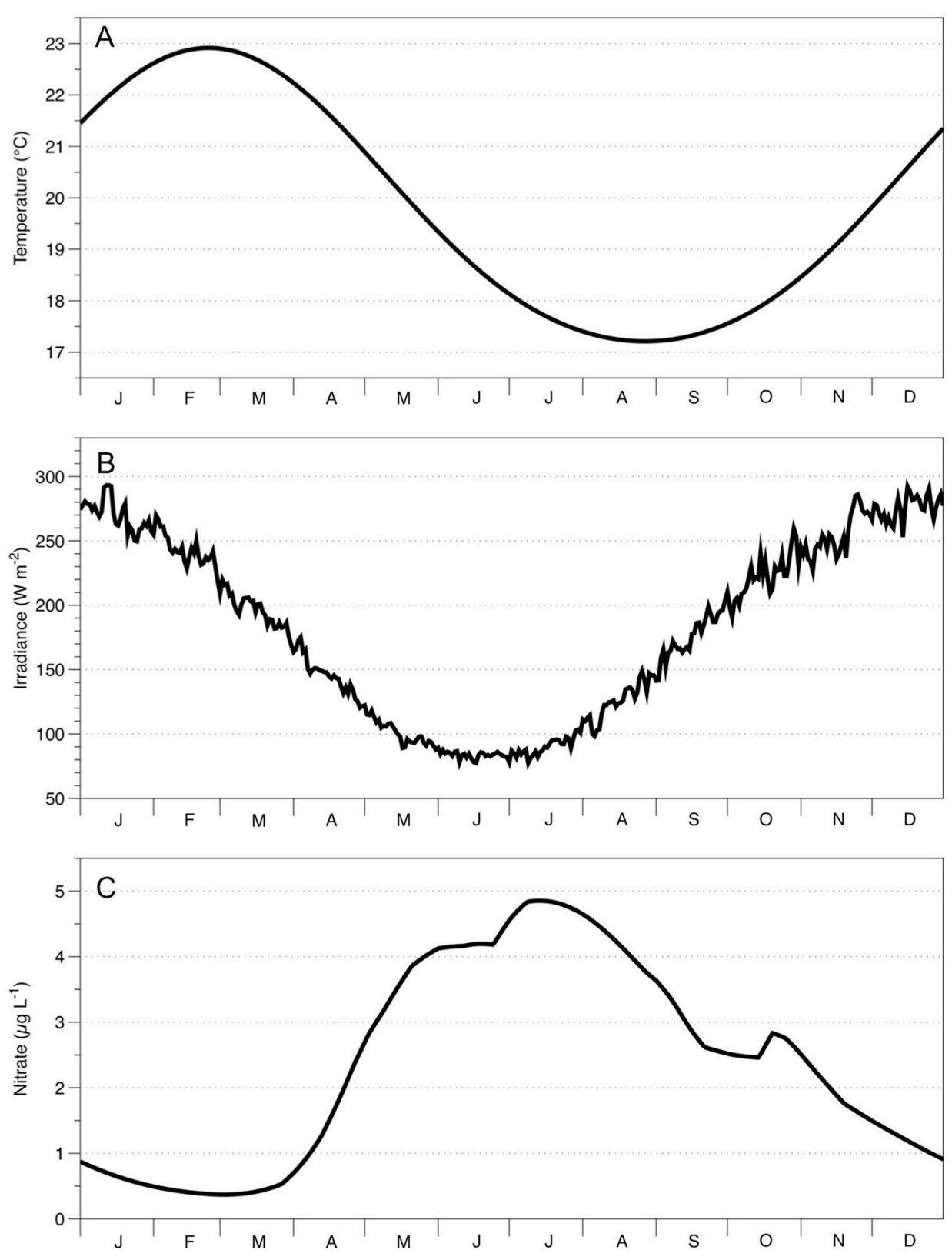

FIGURE 3 | Seasonal climatology of the study area $\left(30^{\circ} \mathrm{S}\right.$ to $40^{\circ} \mathrm{S}, 150^{\circ} \mathrm{E}$ to $\left.160^{\circ} \mathrm{E}\right)$ for (A) surface temperature; (B) surface irradiance; (C) nitrate concentration $\mathbf{5 m}$ below seasonal mixed layer depth. Data for $(\mathbf{A}, \mathbf{C})$ come from the CSIRO Atlas of Regional Seas (CARS) available at

http://www.marine.csiro.au/ dunn/cars2009/. Data for (B) comes from seasonal climatology of the downward short wave radiation at the surface of the ocean (Large and Yeager, 2008).

The goodness of the fit between simulated and observed seasonal climatology of Chl-a was assessed through the Chisquared misfit $\left(\chi^{2}\right)$ :

$$
\chi^{2}=\frac{1}{v} \sum_{t=1}^{T} \frac{\left(Q_{m}^{t}-Q_{o}^{t}\right)^{2}}{\sigma^{t}}
$$

where $Q_{m}^{t}$ is the value of the modeled data at time $t$ and $Q_{o}^{t}$ is the observed value of Chl-a at time $t$, while $\sigma^{t}$ is the variance at time $t$ of the Chl-a climatology. The degrees of freedom are represented by $\nu$ :

$$
v=n_{o}-n_{p}
$$

where $n_{o}$ is the number of observations, and $n_{p}$ is the number of fitted parameters. A $\chi^{2}$ value of $\sim 1$ represents an acceptable model fit to the observations. 

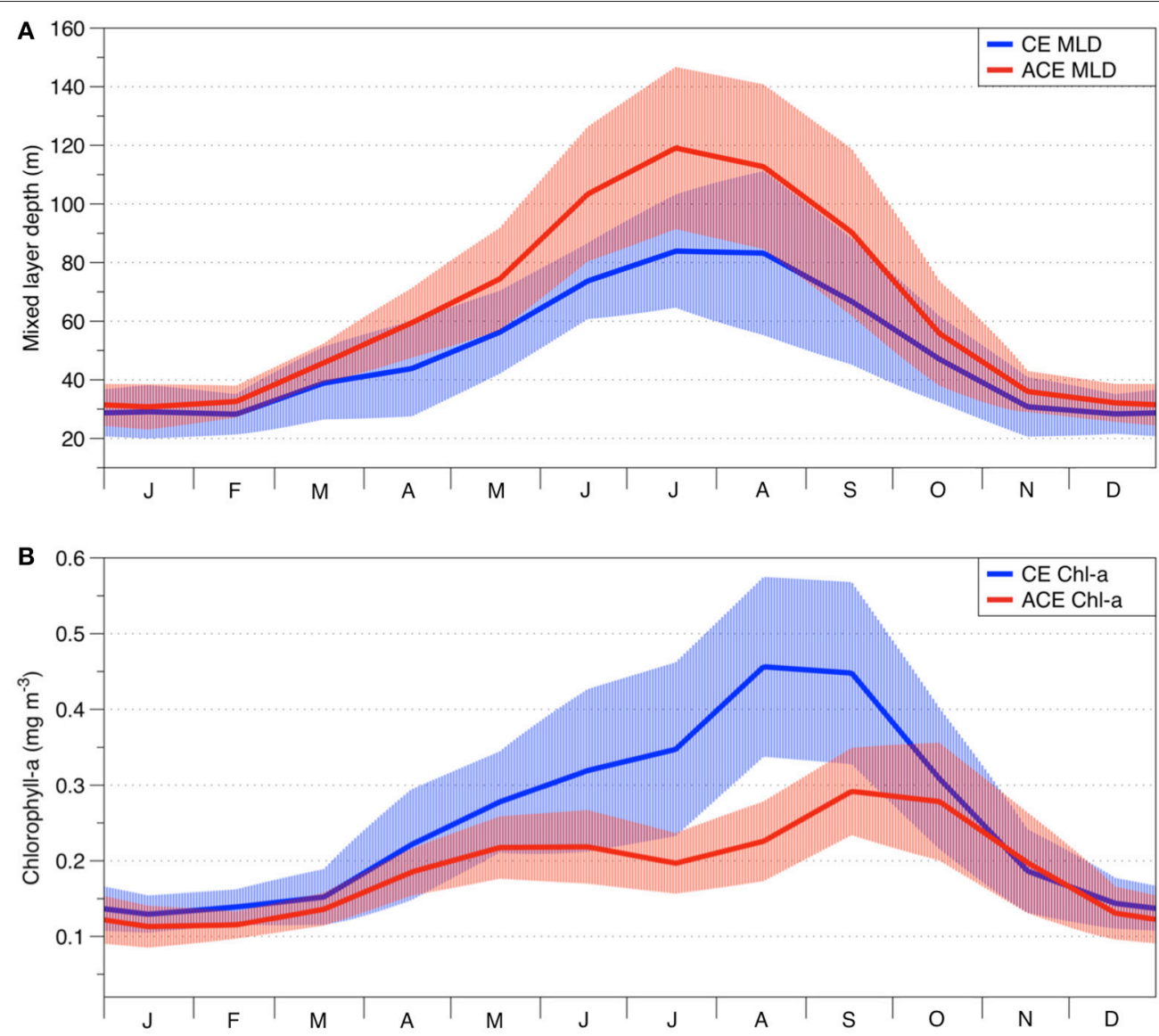

FIGURE 4 | Seasonal climatology of cold core CE (solid blue lines) and warm core ACE (solid red lines) eddies for: (A) mixed layer depth (MLD) (GODAE); (B) surface chlorophyll-a concentration (GlobColour). The light blue and light red areas represent standard deviation for CE and ACE, respectively.

\section{Data Assimilation}

The observed CE and ACE Chl-a seasonal climatologies were used for the data assimilation, with the purpose of finding parameter sets that best fitted the observations from the two environments (e.g., Matear, 1995). The observed Chl-a climatology was assumed to represent the Chl-a concentration in the MLD (i.e., Chl-a uniformly distributed in the MLD). Although this assumption is commonly made, caution needs to be used when interpreting results because a chlorophyll maximum below the surface mixed layer may be not be detected by satellites (e.g., Sallée et al., 2015). To quantify the difference between the simulated and observed Chl-a concentrations we used a cost function $(x)$ defined as:

$$
x=\sum_{t=1}^{T} \frac{\left(\ln \mathrm{Q}_{\mathrm{m}}^{\mathrm{t}}-\ln \mathrm{Q}_{\mathrm{o}}^{\mathrm{t}}\right)^{2}}{n}
$$

where $\mathrm{Q}_{\mathrm{m}}^{\mathrm{t}}$ is the value of the modeled data (total Chl-a concentration) at time $t, \mathrm{Q}_{\mathrm{o}}^{\mathrm{t}}$ is the observed value of Chl-a at time $t$ and $n$ is the number of samples over time. The "In" transformation was applied to achieve normal distribution of the Chl-a concentrations around the mean seasonal value, thus allowing us to employ statistical parametric methods.
To estimate the optimized parameter set for WOMBAT, we used a simulated annealing algorithm based on the likelihood cost metric $(x)$. This approach has been previously used in marine ecosystem models and can solve optimization problems with a small number of unknown parameters (e.g., Matear, 1995; Kidston et al., 2013). The simulated annealing algorithm was run for 200 iterations to allow the algorithm to converge to the minimum cost function value. The data assimilation was performed with WOMBAT, fitting CE and ACE seasonal climatology independently by allowing eight parameters that controlled plankton growth to vary (Table 3). Data assimilation was also used to fit both the environments with one parameter set to determine if the one-phytoplankton class model was sufficiently complex to represent both eddy types.

The data assimilation was then performed with EMS, fitting the $\mathrm{CE}$ and $\mathrm{ACE} \mathrm{Chl}-\mathrm{a}$ seasonal climatology independently and fitting both the environments with one parameter set. Because the simulated annealing algorithm computational requirements are large and EMS is a much more complex model than WOMBAT, we estimated EMS parameters with the conjugategradient algorithm because it was more computationally efficient. Although this algorithm is sensitive to the choice of the initial model parameters, it is used to solve optimization problems with 
TABLE 2 | Results of the statistical comparisons (student $t$-test): Chl-a means (observed vs. simulated, ACE observed vs. CE observed) and MLD means (ACE observed vs. CE observed).

\begin{tabular}{|c|c|c|c|}
\hline & \multirow[b]{2}{*}{$\begin{array}{l}\text { ACE observed } \\
\text { vs. CE observed }\end{array}$} & \multicolumn{2}{|c|}{ Chl-a concentration } \\
\hline & & $\begin{array}{l}\text { ACE model vs. } \\
\text { ACE observed }\end{array}$ & $\begin{array}{l}\text { CE model. vs. } \\
\text { CE observed }\end{array}$ \\
\hline Chl-a climatology & $p=0.0002$ & & \\
\hline MLD climatology & $p=0.006$ & & \\
\hline $\begin{array}{l}\text { WOMBAT (CE and ACE, } \\
2 \text { distinct parameter set) }\end{array}$ & & $\begin{array}{c}\text { N.S. } \\
0.12<p<0.49 \\
0.8<\chi^{2}<1.6\end{array}$ & $\begin{array}{c}\text { N.S. } \\
0.22<p<0.42 \\
0.88<\chi^{2}<1.1\end{array}$ \\
\hline $\begin{array}{l}\text { WOMBAT (CE and ACE, } \\
1 \text { equal parameter set) }\end{array}$ & & $\begin{array}{l}p^{\star \star \star}=0.001 \\
\chi^{2}=1.8\end{array}$ & $\begin{array}{l}p^{*}=0.003 \\
\chi^{2}=1.7\end{array}$ \\
\hline $\begin{array}{l}\text { EMS (CE and ACE, } 2 \\
\text { distinct parameter set) }\end{array}$ & & $\begin{array}{c}\text { N.S. } \\
0.13<p<0.27 \\
1.5<\chi^{2}<2.2\end{array}$ & $\begin{array}{c}\text { N.S. } \\
0.24<p<0.43 \\
0.6<\chi^{2}<1.6\end{array}$ \\
\hline $\begin{array}{l}\text { EMS (CE and ACE, } 1 \\
\text { equal parameter set) }\end{array}$ & & $\begin{array}{c}\star \star \star \\
p=0.0003 \\
\chi^{2}=2.8\end{array}$ & $\begin{array}{l}p^{* *} \\
\chi^{2}=0.002 \\
\chi^{2}=1.9\end{array}$ \\
\hline
\end{tabular}

Results at significance values are highlighted: N.S, indicates not significant $(p>0.05)$; *indicates $p<0.05 ;{ }^{* *} p<0.01$; and ${ }^{* *} p<0.001 . \chi^{2}$ indicates the Chi-squared misfit value: the closer $\chi^{2}$ is to 1 , the more accurate the simulation. In this table, "p" and " $\chi^{2}$ intervals represent the minimum and the maximum value obtained from acceptable solutions. Simulations were considered acceptable when both $p>0.05$ and $\chi^{2}>2.5$.

marine biogeochemical models as well (e.g., Fasham et al., 1995; Evans, 1999). Advantages and disadvantages of using simulated annealing or conjugate-gradient algorithms are discussed in Matear (1995). The phytoplankton size classes in EMS were fixed, with the purpose of representing two distinct phytoplankton types to examine if their abundance was different between $\mathrm{CE}$ and ACE: $2 \mu \mathrm{m}$ diameter for small phytoplankton cells and 40 $\mu \mathrm{m}$ diameter for large phytoplankton cells. With EMS, the data assimilation was allowed to vary 12 parameters-like WOMBAT, they were the parameters controlling plankton growth (Table 4).

To recognize that there was not one unique solution, rather a range of parameter values could produce acceptable solutions, we show a range of simulated behavior to reflect the non-uniqueness of the solution. From data assimilation results, only acceptable solutions are shown, which were simulations where both $0<$ $\chi^{2}<2.5$ and there was no significant difference between the annual mean simulated and observed Chl-a concentration (with 95\% confidence in the equivalence test; Wellek, 2010).

\section{Shipboard Manipulation Experiment}

To investigate the potential shift in phytoplankton size and abundance in a CE we examined phytoplankton responses to increased light and nutrients by performing an experiment during an oceanographic research voyage. The experiment was carried out on board the RV Investigator (voyage IN2015_V03), with water sampled from a station located in the EAC $\left(32.7^{\circ} \mathrm{S}\right.$ and $153.6^{\circ} \mathrm{E}$ ), inside the modeling domain (Figure 1). This site was representative of potential source water for eddies, allowing us to evaluate the effect of light and nutrients on the phytoplankton community prior to the seasonal shoaling of the MLD. Water was sampled a few meters below the MLD $(\sim 110$ $\mathrm{m}$, water temperature $\sim 20.9^{\circ} \mathrm{C}$ ) and exposed to increased light and nutrients. Sampled seawater was transferred directly from the CTD-rosette into 15 acid-cleaned $4 \mathrm{~L}$ polycarbonate vessels. Vessels were sealed, randomly assigned to three light treatments, with half the bottles being amended with inorganic nutrients and the other half remaining unamended, before they were all placed in a deck-board incubator which had continuous flow of surface seawater of $\sim 21.5^{\circ} \mathrm{C}$. The nutrient enrichment consisted of daily nutrient addition of dissolved inorganic Fe III $0.005 \mu \mathrm{mol} \mathrm{L}^{-1}$, $\mathrm{N}$ as nitrate $1.2 \mu \mathrm{mol} \mathrm{L}^{-1}, \mathrm{Si}$ as silicate $1.2 \mu \mathrm{mol} \mathrm{L}^{-1}, \mathrm{P}$ as phosphate $0.075 \mu \mathrm{mol} \mathrm{L}{ }^{-1}$, in Redfield proportion (McAndrew et al., 2007; Ellwood et al., 2013). The experimental treatments included control (CON; ambient light i.e., $\sim 1 \%$ incident light, no nutrient amendment), low light (LL; 20\% incident light), high light (HL; 40\% incident light), low light and nutrients (LL+N), high light and nutrients $(\mathrm{HL}+\mathrm{N})$, and were made in triplicate. Incident light was attenuated using shade cloth. Pigment samples for Ultra-High Performance Liquid Chromatography (UPLC) analysis were collected from each bottle at the end of the 5-day experiment, as well as the initial phytoplankton community.

Samples for UPLC analysis were filtered through $25 \mathrm{~mm}$ glass fiber filters (Whatman GF/F), filters were placed in cryotubes, flash frozen in liquid nitrogen, and stored in a $-80^{\circ} \mathrm{C}$ freezer. The pigment extraction was carried out following a modified method used by Van Heukelem and Thomas (2001). Each filter was placed into an individual $15 \mathrm{~mL}$ falcon tube with $1.5 \mathrm{~mL}$ of chilled $90 \%$ acetone. Each filter was then disrupted using a $40 \mathrm{~W}$ ultrasonic probe for $\sim 30 \mathrm{~s}$, keeping the tube in ice; then the samples were stored at $4^{\circ} \mathrm{C}$ overnight. The sample slurry was vortexed for $10 \mathrm{~s}$ and clarified by passing through a $0.2 \mu \mathrm{m}$ PTFE $13 \mathrm{~mm}$ syringe filter before storage in UPLC glass vials, followed by analysis. The dataset obtained from the UPLC analyses was analyzed following Barlow et al. (2004) formulae and Thompson et al. (2011) for the pigment quality control.

\section{RESULTS}

\section{Characterization of CE and ACE}

The physical environment of the CE and ACE show important differences in their seasonal climatologies. For ACE, the MLD is deeper than $\mathrm{CE}$ throughout the seasonal cycle (Figure 4A; $n=365, p<0.01$, Table 2). Conversely, the surface Chl-a concentrations are higher in CE than ACE for most of the year (Figure 4B, $n=365, p<0.001$, Table 2). Both Chl-a and MLD show the greatest differences between CE and ACE in the May and October period (austral winter/spring); while for the rest of the year (November to April) Chl-a concentrations and MLD are similar (Figure 4).

\section{WOMBAT and EMS Simulations}

Data assimilation to independently determine WOMBAT parameter sets for the $\mathrm{CE}$ and ACE environments produced acceptable simulations of the Chl-a seasonal climatology 
TABLE 3 | WOMBAT parameter set for CE and ACE fitted independently, and the optimized parameter set fitting the two environments simultaneously (CE + ACE).

\begin{tabular}{|c|c|c|c|c|}
\hline Parameter & CE & ACE & $\mathrm{CE}+\mathrm{ACE}$ & Unit \\
\hline Photosynthetic efficiency (initial slope of P-I curve) & $0.020 \pm 0.003$ & $0.024 \pm 0.006$ & 0.024 & $\operatorname{day}^{-1}\left(\mathrm{~W} \mathrm{~m}^{-2}\right)$ \\
\hline Shortwave fraction of photosynthetically active radiation & 0.43 & 0.43 & 0.43 & \\
\hline Half saturation constant for $\mathrm{N}$ uptake & $1.2 \pm 0.1$ & $1.2 \pm 0.1$ & 1.23 & $\mathrm{mmol} \mathrm{m}-3$ \\
\hline \multirow[t]{3}{*}{ Phytoplankton maximum growth rate parameters } & a) $1.6 \pm 0.2$ & $1.7 \pm 0.1$ & 1.8 & day $^{-1}$ \\
\hline & b) 1.066 & 1.066 & 1.066 & \\
\hline & c) 1.0 & 1.0 & 1.0 & \\
\hline Phytoplankton mortality & $0.02 \pm 0.01$ & $0.02 \pm 0.01$ & 0.03 & day $^{-1}$ \\
\hline Zooplankton assimilation efficiency & $0.75 \pm 0.1$ & $0.6 \pm 0.25$ & 0.85 & \\
\hline Zooplankton maximum grazing rate & $2.55 \pm 1.05$ & $2.0 \pm 0.5$ & 1.70 & day $^{-1}$ \\
\hline Zooplankton prey capture rate & $2.9 \pm 1.1$ & $3.1 \pm 0.8$ & 2.86 & $\left(\mathrm{mmol} \mathrm{N} / \mathrm{m}^{2}\right)^{-1}$ day $^{-1}$ \\
\hline Zooplankton (quadratic) mortality & $0.8 \pm 0.1$ & $0.3 \pm 0.2$ & 0.64 & $\left(\mathrm{mmol} \mathrm{N} / \mathrm{m}^{3}\right)^{-1}$ day $^{-1}$ \\
\hline Zooplankton excretion & 0.01 & 0.01 & 0.01 & day $^{-1}$ \\
\hline Remineralization rate & 0.10 & 0.10 & 0.10 & day $^{-1}$ \\
\hline Sinking velocity & 5.00 & 5.00 & 5.00 & $m$ day $^{-1}$ \\
\hline
\end{tabular}

TABLE 4 | EMS parameter set for CE and ACE.

\begin{tabular}{|c|c|c|c|c|}
\hline Parameter & CE & ACE & $\mathrm{CE}+\mathrm{ACE}$ & Unit \\
\hline Large zooplankton growth efficiency & $0.37 \pm 0.03$ & $0.29 \pm 0.05$ & 0.34 & \\
\hline Small zooplankton growth efficiency & $0.33 \pm 0.03$ & $0.27 \pm 0.02$ & 0.30 & \\
\hline Large phytoplankton natural (linear) mortality rate & $0.01 \pm 0.003$ & $0.01 \pm 0.003$ & 0.01 & day $^{-1}$ \\
\hline Small phytoplankton natural (linear) mortality rate & $0.02 \pm 0.008$ & $0.02 \pm 0.01$ & 0.02 & day $^{-1}$ \\
\hline Large zooplankton natural (quadratic) mortality rate & $0.76 \pm 0.15$ & $0.42 \pm 0.08$ & 0.55 & $\left(\mathrm{mmol} \mathrm{N} / \mathrm{m}^{3}\right)^{-1}$ day $^{-1}$ \\
\hline Small zooplankton natural (quadratic) mortality rate & $0.35 \pm 0.02$ & $0.42 \pm 0.08$ & 0.36 & $\left(\mathrm{mmol} \mathrm{N} / \mathrm{m}^{3}\right)^{-1}$ day $^{-1}$ \\
\hline Large phytoplankton maximum growth rate at Tref & $1.85 \pm 0.25$ & $1.7 \pm 0.2$ & 2.0 & day $^{-1}$ \\
\hline Large phytoplankton cells diameter & 40.0 & 40.0 & 40.0 & $\mu \mathrm{m}$ \\
\hline Small phytoplankton maximum growth rate at Tref & $1.1 \pm 0.1$ & $1.1 \pm 0.1$ & 1.1 & day $^{-1}$ \\
\hline Small phytoplankton cells diameter & 2.0 & 2.0 & 2.0 & $\mu \mathrm{m}$ \\
\hline Small zooplankton maximum growth rate of at Tref & $0.38 \pm 0.02$ & $0.4 \pm 0.03$ & 0.41 & day $^{-1}$ \\
\hline Small zooplankton swimming velocity & $0.002 \pm 0.0005$ & $0.0015 \pm 0.0003$ & 0.0022 & $\mathrm{~m} / \mathrm{s}$ \\
\hline Large zooplankton maximum growth rate at Tref & $0.85 \pm 0.25$ & $0.4 \pm 0.1$ & 0.62 & day $^{-1}$ \\
\hline Large zooplankton swimming velocity & $0.052 \pm 0.003$ & $0.06 \pm 0.005$ & 0.058 & $\mathrm{~m} / \mathrm{s}$ \\
\hline Remineralization rate & 0.10 & 0.10 & 0.10 & day $^{-1}$ \\
\hline Sinking velocity & 5.00 & 5.00 & 5.00 & $m$ day $^{-1}$ \\
\hline
\end{tabular}

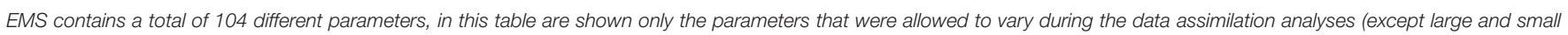
phytoplankton cells diameter, remineralization rate, and sinking velocity).

(Figures 5A,B). Acceptable simulations are demonstrated by the $\chi^{2}$ values and the non-significant $t$-student test (ACE $p>0.12$; CE $p>0.22,95 \%$ confidence that the two dataset are equivalent), confirming that there are no significant differences between the average of the modeled and observed data (Table 2).

The data assimilation carried out with the single phytoplankton model WOMBAT for the two eddy environments yielded distinct parameter sets (Table 3). For acceptable solutions, the main difference between the parameter sets relate to zooplankton (quadratic) mortality, where CE shows $\sim 130 \%$ greater values than ACE (Table 3 ). From the acceptable solutions, we show the primary production and zooplankton concentrations for the two types of eddies (Figures 5C-F). When the data assimilation tries to fit both the environments with a single parameter set there is a significant probability (ACE $p$ $=0.003$; CE $p=0.005$, Table 2) the annual mean Chl-a differs between the observed and simulated value.

The data assimilation carried out with EMS for the two environments leads to acceptable simulation of Chl-a (Table 2), with the simulated annual mean Chl-a consistent with the observed value (ACE $p>0.13$; $\mathrm{CE} p>0.24$, 95\% confidence that the two dataset are equivalent; Figure 6, Table 2). However, no acceptable solutions were found fitting both the environments with one parameter set (Table 2). The data assimilation with EMS produced distinct parameter sets for the $\mathrm{CE}$ and $\mathrm{ACE}$ environments, with main differences 

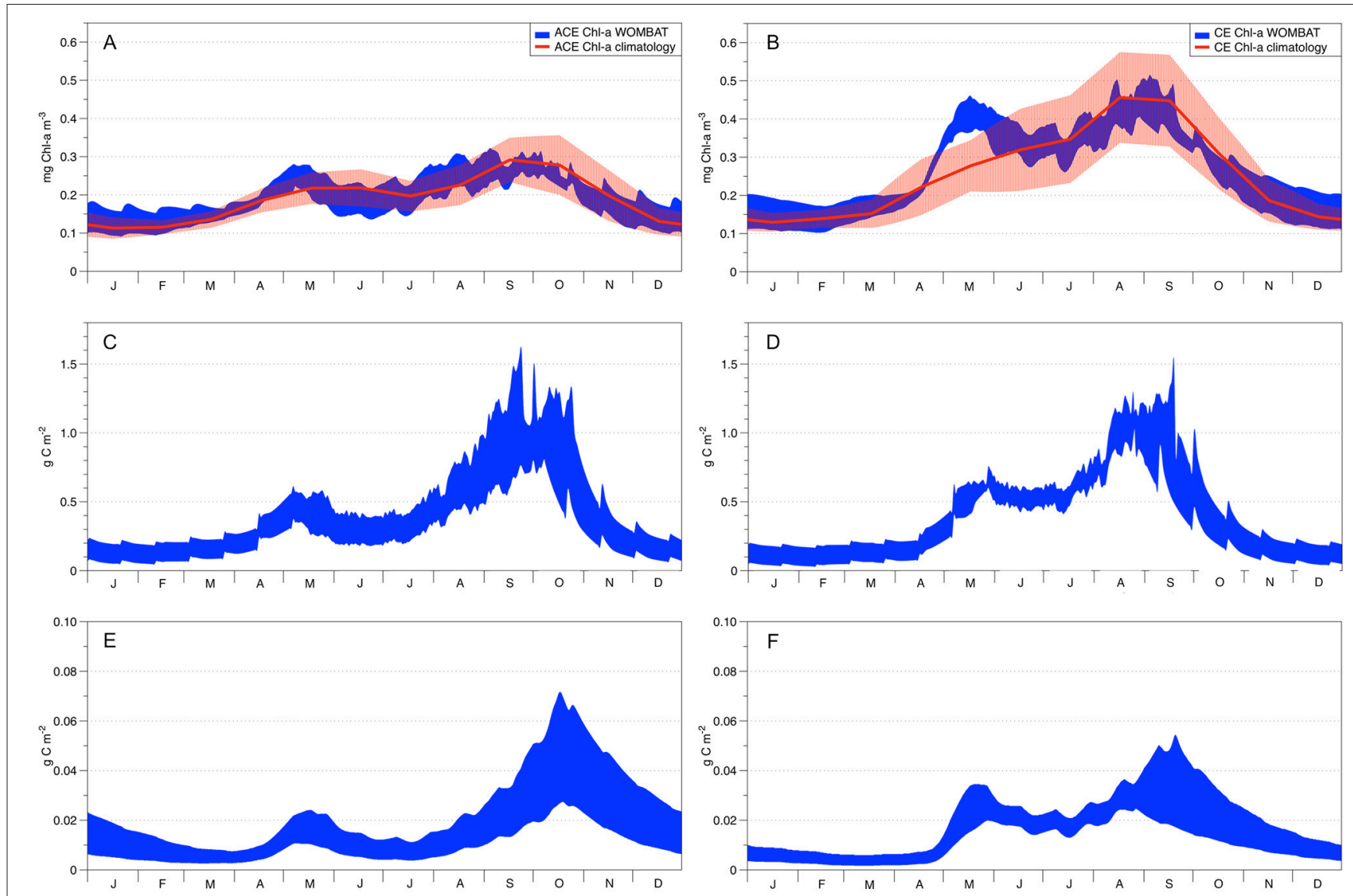

FIGURE 5 | WOMBAT's acceptable solutions obtained from data assimilation. Left column shows ACE seasonality and right column CE seasonality. The red solid lines in plots (A,B) show the Chl-a observed seasonal climatology with the red shading denoting the standard deviation variability. In all remaining plots, the blue areas represent WOMBAT acceptable solutions. Plots (C; ACE) and (D; CE) represent primary production ( $\mathrm{g} \mathrm{C} \mathrm{m}^{-2}$ ) while plots (E,F) represent the zooplankton dynamics for the ACE and CE systems, respectively.

related to the large zooplankton parameters: large zooplankton quadratic mortality rate is $\sim 1.8$ times greater in $\mathrm{CE}$ and large zooplankton maximum growth rate is $\sim 2.1$ times greater in CE (Table 4). For the acceptable EMS solutions we show the primary production for large and small phytoplankton and the seasonal evolution of the small and large zooplankton concentrations (Figures 6C-H). The development of the winter/spring (MayOctober) phytoplankton bloom is driven by increased production of large phytoplankton, that is considerably greater in the CEs than the ACEs.

Simulations carried out to evaluate higher-frequency variations in the MLD (i.e., with the inclusion of random noise), produce plankton dynamics within the range of the acceptable solutions (Figures 5, 6).

\section{Shipboard Manipulation Experiment}

The initial phytoplankton community sampled below the EAC MLD, at $\sim 110 \mathrm{~m}$ in June was composed mainly of picophytoplankton $(<2 \mu \mathrm{m})$ and nanophytoplankton (2-20 $\mu \mathrm{m})$ while the microphytoplankton $(>20 \mu \mathrm{m})$ was the least abundant phytoplankton size class (Figure 7A). Prochlorococcus (as indicated by the concentration of divinyl chlorophylla) and haptophytes (hex-fucoxanthin) were the dominant phytoplankton classes in the initial community (Figure 7B). At the end of the shipboard experiment, the phytoplankton composition (as determined by pigment analyses) was similar in all treatments (Figure 7). By the end of the experiment, there was a large change in the phytoplankton community, highlighting a shift from nano and picophytoplankton to the larger microphytoplankton (Figure 7A) and from Prochlorococcus and haptophytes to diatoms (Figure 7B). The pigment concentrations in the control vessels at the end of the experiment were below detection $\left(>0.004 \mu \mathrm{g} \mathrm{L}^{-1}\right)$, and are hence shown as zero in Figure 7.

\section{DISCUSSION}

\section{The Role of Mixed Layer Depth and Light on Phytoplankton}

Statistical analysis of the MLD and Chl-a seasonal climatologies clearly shows that $\mathrm{CE}$ and $\mathrm{ACE}$ off eastern Australia are two distinct environments (Figure 4, Table 2). Similarities in 

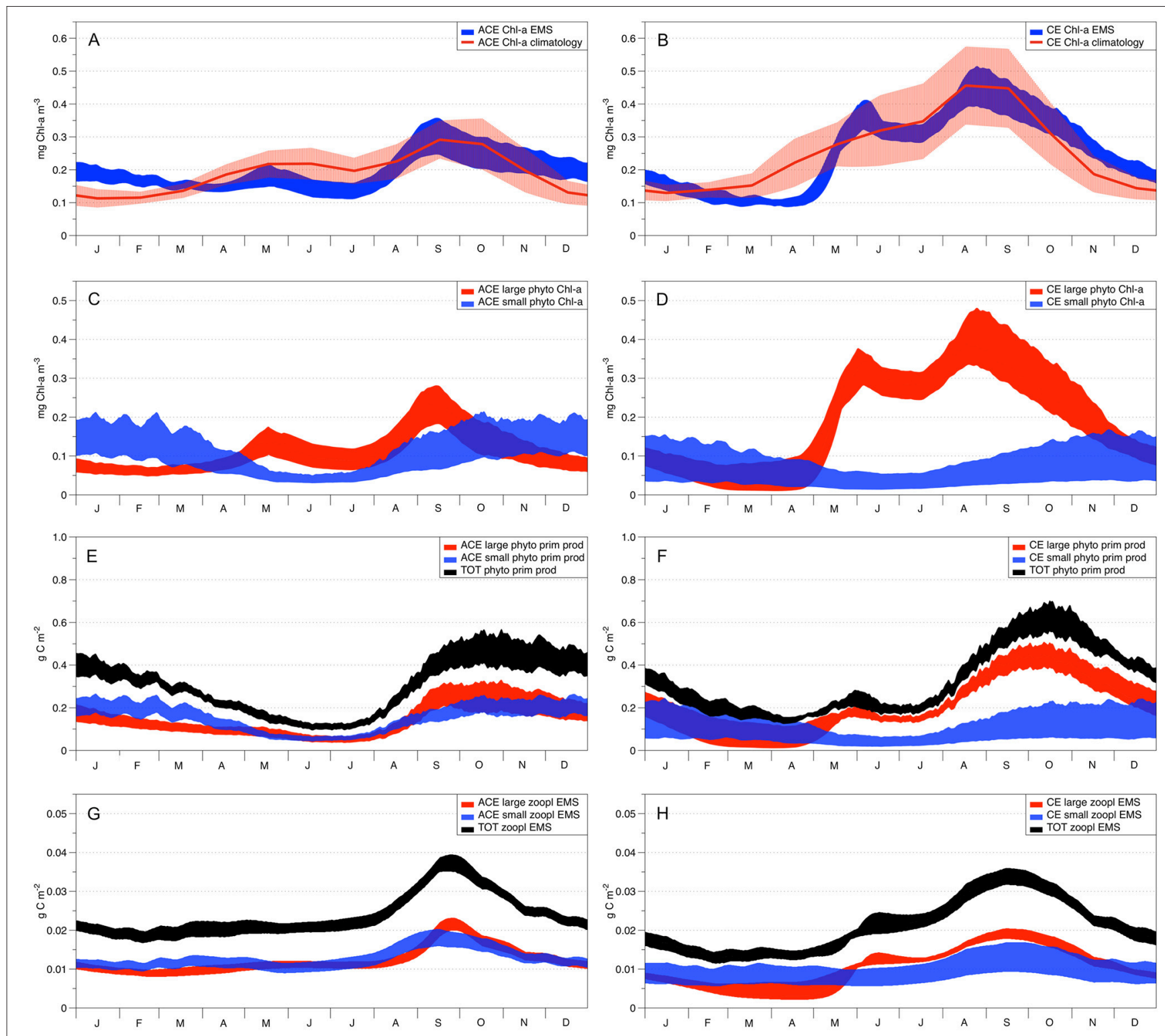

FIGURE 6 | EMS acceptable solutions from the data assimilation. Left column shows ACE seasonality and right column CE seasonality. The red solid lines in plots (A,B) show the Chl-a observed seasonal climatology with the red shading denoting the standard deviation variability. Patterns of the two EMS phytoplankton classes (Chl-a) are represented in plot (C; $\mathrm{ACE})$ and (D; $\mathrm{CE})$, where red areas represent the large phytoplankton class (40 $\mu \mathrm{m}$ diameter) and blue areas represent the small phytoplankton class $\left(2 \mu \mathrm{m}\right.$ diameter). Plots $(\mathbf{E} ; \mathrm{ACE})$ and $(\mathbf{F} ; \mathrm{CE})$ represent the total primary production $\left(\mathrm{g} \mathrm{C} \mathrm{m}^{-2}\right)$ in black and the primary production for small (blue) and large phytoplankton (red). The total zooplankton biomass $\left(\mathrm{g} \mathrm{C} \mathrm{m}^{-2}\right)$ is represented in black on plots (G; ACE) and (H; CE), while the small and large zooplankton biomass is represented in blue and red, respectively.

the MLD and Chl-a seasonal climatology dynamics (Figure 4) suggest the MLD could be a key environmental driver of differences in Chl-a between these two environments. The importance of MLD deepening to Chl-a seasonality in subtropical water is consistent with a recent study of Chl-a variability in eddies of the Indian Ocean (Dufois et al., 2016).

In both the single and multiple box phytoplankton models, the MLD seasonal climatology was enough to drive the phytoplankton dynamics and reflect the observed differences between the CE and ACE environments (Figures 5A,B, 6A,B).
Although our simulations did not take physical dynamics (i.e., sub-mesoscale events) directly into account, these processes are indirectly accounted for by the implementation of observed $\mathrm{CE}$ and ACE MLD.

WOMBAT and EMS simulations confirm that MLD dynamics play an important role in driving the Chl-a concentration in both eddy types. The evolution of the MLD leads to a change in both the nutrient concentration and the light available for photosynthesis, which in turn influences the phytoplankton abundance and community composition (Officier 

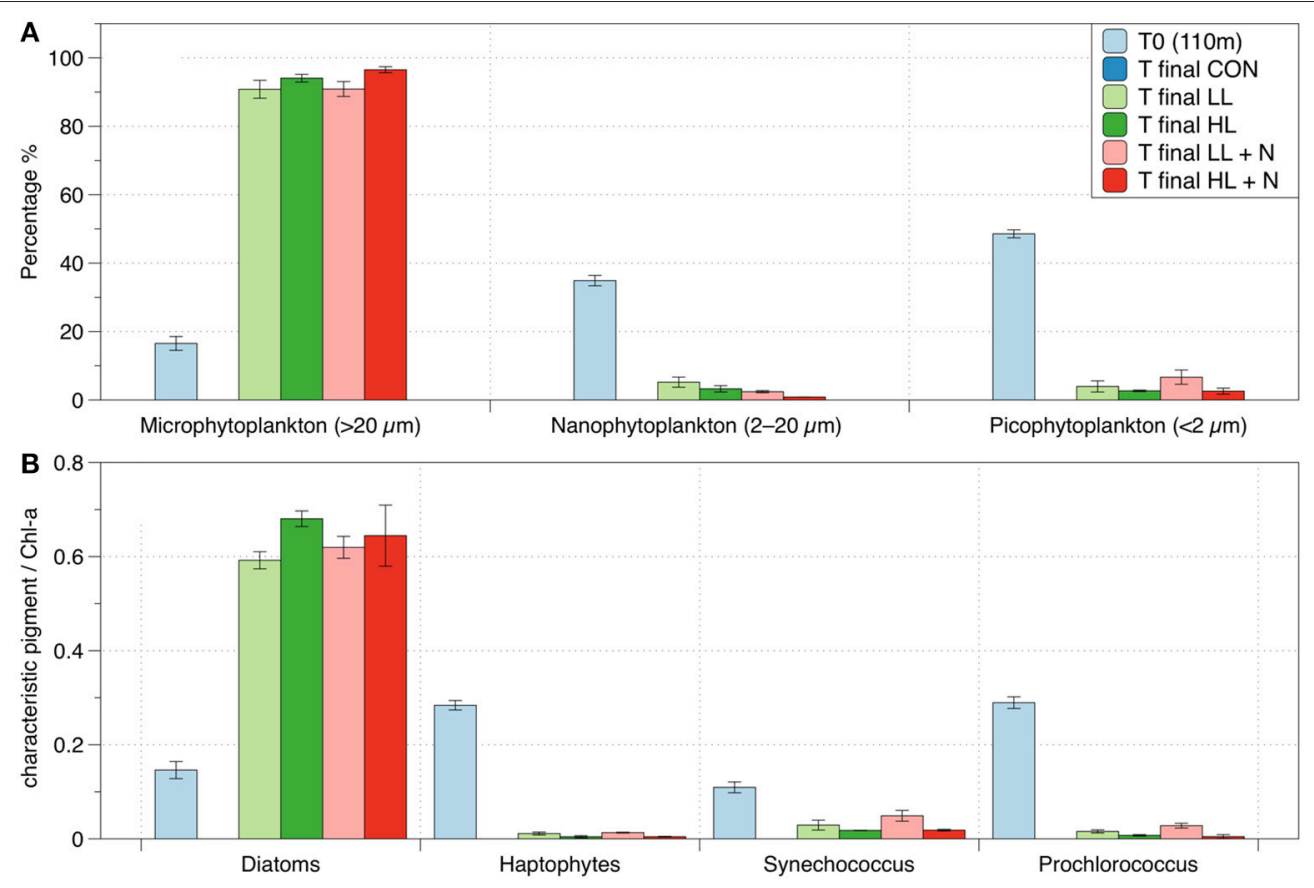

FIGURE 7 | Pigment analysis of phytoplankton in different treatments (shipboard incubation experiment): (A) size distribution at the initial and final time of the experiment; (B) ratio between characteristic phytoplankton classes pigment and total Chl-a (Diatoms: Fucoxanthin, Haptophytes: 19-Hex-fucoxanthin, Synechococcus: Zeaxanthin, Prochlorococcus: DV Chlorophyll a, Barlow et al., 2004). In all panels it is represented the "T0 (110m)" showing the initial condition and the "T final" showing the last day of the experiment (6th day). The treatments are labeled as: LL (20\% surface irradiance), HL (40\% surface irradiance), $\mathrm{N}$ (daily nutrients addition). The control (CON, $\sim 1 \%$ incident light, no nutrient amendment). The CON is not represented at the end of the experiment ( $T$ final) because the pigment concentrations were below detection $(>0.004 \mu \mathrm{g} / \mathrm{L})$.

and Ryther, 1980; Pitcher et al., 1991; Tilburg et al., 2002). The differences in Chl-a and MLD between CE and ACE are greatest in the austral winter/spring when surface light irradiance are near their seasonal minimum (Figure 3B). During the winter/spring period the MLD is deep and it has been shown to cause strong light limitation of phytoplankton growth (Behrenfeld and Boss, 2014). McGillicuddy (2015) hypothesized that in such a light-limited regime, the shallower MLD of the CE than ACE could lead to higher Chl-a concentration in $\mathrm{CE}$.

The shipboard manipulation experiment clarifies the effect of light and nutrients on the phytoplankton community sampled in the same area as our modeling study. The water collected in austral winter from below the MLD $(110 \mathrm{~m})$ originally contained a low abundance of phytoplankton (total Chl-a concentration $0.068 \pm 0.003 \mu \mathrm{g} \mathrm{L}^{-1}$, mean \pm standard deviation). After being exposed to $1 \%$ surface light (ambient irradiance at the sampling depth) for 6 days, phytoplankton were undetectable $(<0.004$ $\mu \mathrm{g}$ Chl-a $\mathrm{L}^{-1}$ ), confirming they did not have enough light to remain viable. The same phytoplankton community exposed to 20 and $40 \%$ surface irradiance resulted in growth and showed a similar shift in community structure whether nutrients were added or not (Figure 7A). The shipboard experiment reveals that, in this region, during winter while the MLD is still deepening (Figure 4A), the phytoplankton growth is limited by light rather than by nutrients.

\section{Phytoplankton Composition and Size Structure}

During the shipboard experiment with elevated light, the phytoplankton community shifted from picophytoplankton $(<2$ $\mu \mathrm{m} ; \sim 49 \%$ of the initial community) and nanophytoplankton (2$20 \mu \mathrm{m}$; $35 \%$ of the initial community) to microphytoplankton (>20 $\mu \mathrm{m}$; $\sim 90 \%$ of the final community; Figure 7A). The microphytoplankton appear most light-limited because they are initially in lowest abundance and then dominate the community when exposed to elevated light. The microphytoplankton are almost totally composed of fucoxanthin-containing cells, most likely reflecting diatoms (Figure 7B).

Data assimilation with WOMBAT and EMS showed that both models could represent the seasonal evolution of Chla in the two types of eddies if the two environments had different parameter values (Table 2). The physical and chemical environment that characterizes the CE in oligotrophic oceans, generally drives the accumulation of large phytoplankton species such as diatoms, while small phytoplankton species and cyanobacteria are more characteristic of the surrounding waters and ACE (Jeffrey and Hallegraeff, 1980; Olaizola et al., 1993; Rodriguez et al., 2003; Vaillancourt et al., 2003; Brown et al., 2008). EMS simulations are consistent with such behavior where different phytoplankton dominate CE and ACE (Figure 6). In particular, EMS simulations show the differences between $\mathrm{CE}$ and ACE Chl-a concentrations are attributed to the large 
phytoplankton class, while the small phytoplankton class has similar dynamics in both the systems (Figures 6C,D). The greatest difference in the EMS simulated large phytoplankton occurs between May and October when observed Chl-a shows the greatest differences between the ACE and CE Chl-a (Figure 6).

Trying to get WOMBAT to use one parameter set to represent both $\mathrm{CE}$ and ACE failed to satisfactorily represent Chla observations (Table 2). WOMBAT's failure to represent the two environments with a unique parameter set may be expected for a model that does not resolve different plankton sizes. However, the parameter values from fitting the two environments separately are very similar. Furthermore, EMS with its two sizes of phytoplankton shows a similar pattern to WOMBAT, where model simulations are unable to produce an acceptable Chl-a simulation using one parameter set to represent both $\mathrm{ACE}$ and CE. This suggests that it is more than phytoplankton size that is driving differences between Chl-a in CEs and ACEs.

\section{Zooplankton}

For both WOMBAT and EMS, the optimized parameter sets suggest that the zooplankton in $\mathrm{CE}$ have twice the mortality rate and nearly double the growth rate compared to the ACE (Tables 3, 4). Hence, in both models, the phytoplankton grow better in CE than in ACE, because of the higher mortality of their grazers which reduces top-down grazing pressure. Bakun (2006) suggests that an enhanced primary production (typical of CEs) improves zooplankton growth but comes at a cost of increased zooplankton predator abundance; this concept is consistent with the higher zooplankton mortality and growth rate obtained from the parameter optimization in the CE system (Tables 3, 4). Another possible explanation is that two distinct zooplankton communities characterize CE and $\mathrm{ACE}$, with higher grazing pressure in CE environments. Such behavior is consistent with the water in CEs from this region tending to have more coastal organisms than ACEs (Macdonald et al., 2016). However, the interpretation of the difference in zooplankton behavior requires some caution because it may be related to eddy dynamics not directly considered in our simulations (i.e., sub-mesoscale interactions). While the differences in zooplankton properties between CE and ACE is a robust feature of the model simulations, additional observations are needed to confirm this result, and determine the mechanism responsible.

\section{CONCLUSION}

Biogeochemical models are increasingly considering phytoplankton composition to characterize elemental cycles in the contemporary and future ocean (Finkel et al., 2009; Follows and Dutkiewicz, 2011). This study shows that inclusion of multiple phytoplankton groups provides useful, and potentially unexpected, insights about ecosystem dynamics, demonstrating divergent accumulation of biomass in different phytoplankton and zooplankton size classes in CE and ACE.

To put the impact and relevance of these mesoscale features in eastern Australian waters into perspective, an average of 13 $\mathrm{CE}$ and $15 \mathrm{ACE}$ with a lifetime $\geq 10$ weeks occur annually in the study region (obtained from Chelton et al., 2011 eddy database, yearly average from 1 December 2002 to 4 April 2012). Given that the primary productivity in East Australia is projected to increase $10 \%$ by the 2060 s due to an increase in eddy activity (Matear et al., 2013), it is therefore critical to quantify plankton concentration, composition, and functioning within eddies and adjacent water masses to advance our understanding of their ecological and trophic roles and impacts to regional fisheries and biogeochemical cycling.

\section{AUTHOR CONTRIBUTIONS}

LL, AM, RM, and MD conceived and designed the experiment. LL and RM acquired the data, performed the modeling work, and analyse the data. LL, AM, and MD performed the ship-based experiment. LL drafted the work, prepared figures, and tables; all authors critically revised the work.

\section{FUNDING}

This research was supported by the Australian Research Council Discovery Projects funding scheme (DP140101340), the Marine National Facility, and the School of Life Science, University of Technology Sydney (postgraduate scholarship to LL), and the Climate Change Cluster research institute (operational support).

\section{ACKNOWLEDGMENTS}

We would like to acknowledge the valuable reviews provided by the two reviewers, which has helped improve the clarity and focus of the manuscript. LL would like to thank Mark Baird, Farhan Rizwi, and Mathieu Mongin (CSIRO) for their useful suggestions and explanations about the Environmental Modeling Suite (EMS), Olivier Laczka (UTS) for his assistance with setting up the experiment aboard the RV Investigator and Gabriela Semolini Pilo (UTAS) for the useful conversations about eddy dynamics. This research was supported by the Australian Research Council Discovery Projects funding scheme (DP140101340 awarded to MD and RM), the Marine National Facility, and the School of Life Science, University of Technology Sydney (postgraduate scholarship to LL) and the Climate Change Cluster research institute (operational support). The authors would like to acknowledge the captain and crew of the IN2015_V03 voyage, as well as the chief scientist, Prof. Iain Suthers. Furthermore, we would like to thank GlobColour, AVISO and the International Argo Program for the production and distribution of the dataset used in this study. 


\section{REFERENCES}

ACRI-ST GlobColour Team, Mangin, A., and Fanton d'Andon, O. (2015). GlobColour Product User Guide, GC-UM-ACR-PUG-01, Version 3.2. SophiaAntipolis.

Angel, M. V., and Fasham, M. J. R. (1983). "Eddies and biological processes," in Eddies in Marine Science, Chap. 22, ed A. R. Robinson (Berlin: Springer), 492-524.

Arístegui, J., and Montero, M. F. (2005). Temporal and spatial changes in plankton respiration and biomass in the Canary Islands region: the effect of mesoscale variability. J. Mar. Syst. 54, 65-82. doi: 10.1016/j.jmarsys.2004. 07.004

Arístegui, J., Tett, P., Hernandez-Guerra, A., Basterretxea, G., Montero, M. F., Wild, K., et al. (1997). The influence of island-generated eddies on chlorophyll distribution: a study of mesoscale variation around Gran Canaria. Deep Sea Res. 44, 71-96. doi: 10.1016/S0967-0637(96)00093-3

Baird, M. E., Ralph, P. J., Rizwi, F., Wild-Allen, K. A., and Steven, A. D. L. (2013). A dynamic model of the cellular carbon to chlorophyll ratio applied to a batch culture and a continental shelf ecosystem. Limnol. Oceanogr. 58, 1215-1226. doi: 10.4319/lo.2013.58.4.1215

Bakun, A. (2006). Fronts and eddies as key structures in the habitat of marine fish larvae: opportunity, adaptive response and competitive advantage. Sci. Mar. 70S2, 105-122. doi: 10.3989/scimar.2006.70s2105

Barlow, R., Aiken, J., Moore, G. F., Holligan, P. M., and Lavender, S. (2004). Pigment adaptations in surface phytoplankton along the eastern boundary of the Atlantic Ocean. Mar. Ecol. Prog. Ser. 281, 13-26. doi: 10.3354/meps281013

Behrenfeld, M. J., and Boss, E. S. (2014). Resurrecting the ecological underpinnings of ocean plankton blooms. Ann. Rev. Mar. Sci. 6, 167-194. doi: 10.1146/annurev-marine-052913-021325

Bibby, T. S., and Moore, C. M. (2011). Silicate:nitrate ratios of upwelled waters control the phytoplankton community sustained by mesoscale eddies in subtropical North Atlantic and Pacific. Biogeosciences 8, 657-666. doi: 10.5194/bg8-657-2011

Bopp, L., Resplandy, L., Orr, J. C., Doney, S. C., Dunne, J. P., Gehlen, M., et al. (2013). Multiple stressors of ocean ecosystems in the 21st century: projections with CMIP5 models. Biogeosciences 10, 6225-6245. doi: 10.5194/bg-10-62252013

Boyd, P. W., and Doney, S. C. (2002). Modelling regional responses by marine pelagic ecosystems to global climate change. Geophys. Res. Lett. 29, 53-1-53-4. doi: 10.1029/2001GL014130

Brainerd, K. E., and Gregg, M. C. (1995). Surface mixed and mixing layer depths. Deep Sea Res. 42, 1521-1543. doi: 10.1016/0967-0637(95)00068-H

Brieva, D., Ribbe, J., and Lemckert, C. (2015). Is the East Australian Current causing a marine ecological hot-spot and an important fisheries near Fraser Island, Australia? Estuar. Coast. Shelf Sci. 153, 121-134. doi:10.1016/j.ecss.2014.12.012

Brown, S. L., Landry, M. R., Selph, K. E., Jin Yang, E., Rii, Y. M., and Bidigare, R. R. (2008). Diatoms in the desert: plankton community response to a mesoscale eddy in the subtropical North Pacific. Deep Sea Res. II Top. Stud. Oceanogr. 55, 1321-1333. doi: 10.1016/j.dsr2.2008.02.012

Chelton, D. B., Schlax, M. G., and Samelson, R. M. (2011). Global observations of nonlinear mesoscale eddies. Prog. Oceanogr. 91, 167-216. doi:10.1016/j.pocean.2011.01.002

Cresswell, G. R. (1994). Nutrient enrichment of the Sydney continental shelf. Aust. J. Mar. Freshw. Res. 45, 677-691. doi: 10.1071/MF9940677

CSIRO Coastal Environmental Modelling Team, (2014). CSIRO Environmental Modelling Suite: Scientific Description of the Optical, Carbon Chemistry and Biogeochemical Models Parameterised for the Great Barrier Reef. Hobart, TAS: Commonwealth Scientific and Industrial Research Organisation Marine and Atmospheric Research.

de Boyer Montegut, C., Madec, G., Fischer, A. S., Lazar, A., and Iudicone, D. (2004). Mixed layer depth over the global ocean: an examination of profile data and a profile-based climatology. J. Geophys. Res. 109, C12003. doi: 10.1029/2004jc002378

Dong, S., Sprintall, J., Gille, S. T., and Talley, L. (2008). Southern ocean mixed-layer depth from argo float profiles. J. Geophys. Res. 113:C06013 doi: 10.1029/2006jc004051
Dufois, F., Hardman-Mountford, N. J., Greenwood, J., Richardson, A. J., Feng, M., Herbette, S., et al. (2014). Impact of eddies on surface chlorophyll in the South Indian Ocean. J. Geophys. Res. Oceans 119, 8061-8077. doi: $10.1002 / 2014$ jc010164

Dufois, F., Hardman-Mountford, N. J., Greenwood, J., Richardson, A. J., Feng, M., and Matear, R. J. (2016). Anticyclonic eddies are more productive than cyclonic eddies in subtropical gyres because of winter mixing. Sci. Adv. 2:e1600282. doi: 10.1126/sciadv.1600282

Ellwood, M. J., Law, C. S., Hall, J., Woodward, E. M. S., Strzepek, R., Kuparinen, J., et al. (2013). Relationships between nutrient stocks and inventories and phytoplankton physiological status along an oligotrophic meridional transect in the Tasman Sea. Deep Sea Res. I 72, 102-120. doi: 10.1016/j.dsr.2012.11.001

Evans, G. T. (1999). The role of local models and data sets in the joint global ocean flux study. Deep Sea Res. I 46, 1369-1389. doi: 10.1016/S0967-0637(99) 00010-2

Everett, J. D., Baird, M. E., Oke, P. R., and Suthers, I. M. (2012). An avenue of eddies: Quantifying the biophysical properties of mesoscale eddies in the Tasman Sea. Geophys. Res. Lett. 39:L16608. doi: 10.1029/2012GL053091

Falkowski, P. G., Ziemann, D., Kolber, Z., and Bienfang, P. (1991). Role of eddy pumping in enhancing primary production in the ocean. Nature $352,55-58$. doi: $10.1038 / 352055 \mathrm{a} 0$

Fasham, M. J., Evans, G. T., Kiefer, D. A., Creasey, M., and Leach, H. (1995). The use of optimization techniques to model marine ecosystem dynamics at the JGOFS station at 47 degrees N 20 degrees W. Philos. Trans. R. Soc. Lond. B Biol. Sci. 348, 203-209. doi: 10.1098/rstb.1995.0062

Fennel, W., and Neumann, T. (2004). Introduction to the Modelling of Marine Ecosystems. Amsterdam: Elsevier Oceanography Series.

Finkel, Z. V., Beardall, J., Flynn, K. J., Quigg, A., Rees, T. A. V., and Raven, J. A. (2009). Phytoplankton in a changing world: cell size and elemental stoichiometry. J. Plankton Res. 32, 119-137. doi: 10.1093/plankt/fbp098

Follows, M. J., and Dutkiewicz, S. (2011). Modeling diverse communities of marine microbes. Ann. Rev. Mar. Sci. 3, 427-451. doi: 10.1146/annurevmarine-120709-142848

Hamon, B. V. (1965). The East Australian Current, 1960-1964. Deep Sea Res. 12, 889-921. doi: 10.1016/0011-7471(65)90813-2

Haury, L. R. (1984). An offshore eddy in the california current system part IV: plankton distributions. Prog. Oceanogr. 13, 95-111. doi: 10.1016/00796611(84)90007-7

Hobday, A. J., and Hartmann, K. (2006). Near real-time spatial management based on habitat predictions for a longline bycatch species. Fish. Manag. Ecol. 13, 365-380. doi: 10.1111/j.1365-2400.2006.00515.x

Huang, B., Hu, J., Xu, H., Cao, Z., and Wang, D. (2010). Phytoplankton community at warm eddies in the northern South China Sea in winter 2003/2004. Deep Sea Res. II 57, 1792-1798. doi: 10.1016/j.dsr2.2010.04.005

Jeffrey, S. W., and Hallegraeff, G. M. (1980). Studies of phytoplankton species and photosynthetic pigments in a warm core eddy of the East Australian Current. I. Summer populations. Mar. Ecol. Prog. Ser. 3, 285-294.

Jenkins, W. (1988). Nitrate flux into the euphotic zone near Bermuda. Nature 331, 521-523. doi: 10.1038/331521a0

Kidston, M., Matear, R., and Baird, M. E. (2011). Parameter optimisation of a marine ecosystem model at two contrasting stations in the Sub-Antarctic Zone. Deep Sea Res. II 58, 2301-2315. doi: 10.1016/j.dsr2.2011.05.018

Kidston, M., Matear, R., and Baird, M. E. (2013). Phytoplankton growth in the Australian sector of the Southern Ocean, examined by optimising ecosystem model parameters. J. Mar. Syst. 128, 123-137. doi: 10.1016/j.jmarsys.2013.04.01

Klein, P., and Lapeyre, G. (2009). The oceanic vertical pump induced by mesoscale and submesoscale turbulence. Ann. Rev. Mar. Sci. 1, 351-375. doi: 10.1146/annurev.marine.010908.163704

Large, W. G., and Yeager, S. G. (2008). The global climatology of an interannually varying air-sea flux data set. Clim. Dyn. 33, 341-364. doi: 10.1007/s00382-0080441-3

Lee-Lueng, F., Chelton, D. B., Le Traon, P., and Morrow, R. (2010). Eddy dynamics from satellite altimetry. Oceanography 23, 14-25. doi: 10.5670/oceanog. 2010.02

Levy, M., Klein, P., and Treguier, A.-M. (2001). Impact of sub-mesoscale physics on production and subduction of phytoplankton in an oligotrophic regime. J. Mar. Res. 59, 535-565. doi: 10.1357/002224001762842181 
Lochte, K., and Pfannkuche, O. (1987). Cyclonic cold-core eddy in the eastern North Atlantic. II. Nutrients, phytoplankton and bacterioplankton. Mar. Ecol. Prog. Ser. 39, 153-164.

Macdonald, H. S., Roughan, M., Baird, M. E., and Wilkin, J. (2016). The formation of a cold-core eddy in the East Australian Current. Cont. Shelf Res. 114, 72-84. doi: 10.1016/j.csr.2016.01.002

Mata, M. M., Tomczak, M., Wijffels, S., and Church, J. A. (2000). East Australian Current volume transports at 30 degrees S: estimates from the World ocean circulation experiment hydrographic sections PR11/P6 and the PCM3 current meter array. J. Geophys. Res. Oceans 105, 28509-28526. doi: 10.1029/1999JC000121

Matear, R. (1995). Parameter optimization and analysis of ecosystem models using simulated annealing: a case study at Station P. J. Mar. Res. 53, 571-607. doi: $10.1357 / 0022240953213098$

Matear, R. J., Chamberlain, M. A., Sun, C., and Feng, M. (2013). Climate change projection of the Tasman Sea from an Eddy-resolving Ocean Model. J. Geophys. Res. Oceans 118, 2961-2976. doi: 10.1002/jgrc. 20202

McAndrew, P. M., Bjorkman, K. M., Church, M. J., Morris, P. J., Jachowski, N., Williams, P. J. B., et al. (2007). Metabolic response of oligotrophic plankton communities to deep water nutrient enrichment. Mar. Ecol. Prog. Ser. 332, 63-75. doi: 10.3354/meps332063

McGillicuddy, D. (2015). Mechanisms of Physical - Biological - Biogeochemical Interaction at the Oceanic Mesoscale. Ann. Rev. Mar. Sci. 8, 13.1-13.36. doi: 10.1146/annurev-marine-010814-015606

McGillicuddy, D., and Robinson, A. (1997). Eddy-induced nutrient supply and new production in the Sargasso Sea. Deep Sea Res. I 44, 1427-1450. doi: 10.1016/S0967-0637(97)00024-1

McWilliams, J. C. (2008). The nature and consequences of oceanic eddies. Ocean Modeling in an Eddying Regime. Am. Geophys. Union 177, 5-15. doi: 10.1029/177GM03

Moore, T. S. I. I., Matear, R. J., Marra, J., and Clementson, L. (2007). Phytoplankton variability off the Western Australian Coast: mesoscale eddies and their role in cross-shelf exchange. Deep Sea Res. II Top. Stud. Oceanogr. 54, 943-960. doi: 10.1016/j.dsr2.2007.02.006

Officier, C. B., and Ryther, J. H. (1980). The possible importance of silicon in marine eutrophication. Mar. Ecol. Prog. Ser. 3, 83-91. doi: 10.3354/meps 003083

Oke, P. R., and Griffin, D. A. (2011). The cold-core eddy and strong upwelling off the coast of New South Wales in early 2007. Deep Sea Res. II 58, 574-591. doi: 10.1016/j.dsr2.2010.06.006

Olaizola, M., Ziemann, D. A., Bienfang, P. K., Walsh, W. A., and Conquest, L. D. (1993). Eddy-induced oscillations of the pycnocline affect the floristic composition and depth distribution of phytoplankton in the subtropical Pacific. Mar. Biol. 116, 533-542. doi: 10.1007/BF00355471

Pilo, G. S., Mata, M. M., and Azevedo, J. L. L. (2015). Eddy surface properties and propagation at Southern Hemisphere western boundary current systems. Ocean Sci. 11, 629-641. doi: 10.5194/os-11-629-2015

Pitcher, G. C., Walker, D. R., Mitchell-Innes, B. A., and Moloney, C. L. (1991). Short-term variability during an anchor station study in the southern Benguela upwelling system: phytoplankton dynamics. Prog. Oceanogr. 28, 39-64. doi: 10.1016/0079-6611(91)90020-M
Ridgway, K. R., and Dunn, J. R. (2003). Mesoscale structure of the mean East Australian Current System and its relationship with topography. Prog. Oceanogr. 56, 189-222. doi: 10.1016/S0079-6611(03)00004-1

Ridgway, K. R., Dunn, J. R., and Wilkin, J. L. (2002). Ocean interpolation by four-dimensional least squares -Application to the waters around Australia. J. Atmos. Ocean. Technol. 19, 1357-1375. doi: 10.1175/15200426(2002)019<1357:OIBFDW>2.0.CO;2

Robinson, A. R. (Ed.). (1983). Eddies in Marine Science. New York, NY: Springer, 609.

Rodriguez, F., Varela, M., Fernandez, E., and Zapata, M. (2003). Phytoplankton and pigment distributions in an anticyclonic slope water oceanic eddy (SWODDY) in the southern Bay of Biscay. Mar. Biol. 143, 995-1011. doi: 10.1007/s00227003-1129-1

Roemmich, D., Gilson, J., Willis, J., Sutton, P., and Ridgway, K. (2005). Closing the time-varying mass and heat budgets for large ocean areas: the Tasman box. $J$. Clim. 18, 2330-2343. doi: 10.1175/JCLI3409.1

Roughan, M., and Middleton, J. H. (2002). A comparison of observed upwelling mechanisms off the east coast of Australia. Cont. Shelf Res. 22, 2551-2572. doi: 10.1016/S0278-4343(02)00101-2

Sallée, J. B., Llort, J., Tagliabue, A., and Levy, M. (2015). Characterization of distinct bloom phenology regimes in the Southern Ocean. ICES J. Mar. Sci. 72, 1985-1998. doi: 10.1093/icesjms/fsv069

Thompson, P. A., Bonham, P., Waite, A. M., Clementson, L. A., Cherukuru, N., Hassler, C., et al. (2011). Contrasting oceanographic conditions and phytoplankton communities on the east and west coasts of Australia. Deep Sea Res. II 58, 645-663. doi: 10.1016/j.dsr2.2010.10.003

Tilburg, C., Subrahmanyam, B., and O'Brien, J. (2002). Ocean color variability in the Tasman sea. Geophys. Res. Lett. 29, 1487-1490. doi: 10.1029/2001GL014071

Tranter, D. J., Carpenter, D. J., and Leech, G. S. (1986). The coastal enrichment effect of the East Australian Current eddy field. Deep Sea Res. 33, 1705-1721. doi: 10.1016/0198-0149(86)90075-0

Vaillancourt, R. D., Marra, J., Seki, M. P., Parsons, M. L., and Bidigare, R. R. (2003). Impact of a cyclonic eddy on phytoplankton community structure and photosynthetic competency in the subtropical North Pacific Ocean. Deep Sea Res. I 50, 829-847. doi: 10.1016/S0967-0637(03)00059-1

Van Heukelem, L., and Thomas, C. S. (2001). Computer-assisted high-performance liquid chromatography method development with applications to the isolation and analysis of phytoplankton pigments. J. Chromatogr. A 910, 31-49. doi: 10.1016/S0378-4347(00)00603-4

Wellek, S. (2010). Testing Statistical Hypotheses of Equivalence. Boca Raton, FL: Chapman and Hall/CRC, 431.

Conflict of Interest Statement: The authors declare that the research was conducted in the absence of any commercial or financial relationships that could be construed as a potential conflict of interest.

Copyright (C) 2016 Laiolo, McInnes, Matear and Doblin. This is an open-access article distributed under the terms of the Creative Commons Attribution License (CC BY). The use, distribution or reproduction in other forums is permitted, provided the original author(s) or licensor are credited and that the original publication in this journal is cited, in accordance with accepted academic practice. No use, distribution or reproduction is permitted which does not comply with these terms. 